\title{
Exclusive Distribution and Non-Compete Clause in Trade: Transnational Agreements in European Union and United States
}

\author{
Noona Hanni \\ Faculty of Law, University of Turku, Finland
}

Article Received: 13 ${ }^{\text {th }}$ March 2019; Accepted: 22 $2^{\text {nd }}$ July 2019; Published: $31^{\text {st }}$ July 2019

\begin{abstract}
Exclusive distribution agreements are commonly used in both European Union (EU) and United States (US) markets to ensure the efficient distribution of products and services. This article compares the competition legislation in the EU and US and focuses on the differences in the treatment of vertical agreements. This topic is addressed also from an economic perspective and focuses on the possible abuse of dominant market position by international multisectoral companies. This article focuses on the following legal and economic questions: how do competition legislations regulating vertical agreements differ in EU and US and, what kind of possible effects do transnational exclusive distribution agreements have on international trade and competition. In EU law exclusive distribution agreements, even those which include a non-compete obligation limited to five years, are considered as lawful restrictions on competition as long as they fulfil certain criteria listed in the Block Exemption Regulation. EU competition law recognizes the terms of block exemption and 'safe haven', whereas the US antitrust law does not regulate any exemptions to vertical restraints. Vertical restraints are interpreted in the US common law of antitrust in the light of the principle of Rule of Reason. An important difference in these jurisdictions is the definition of relevant markets, which is taken into consideration when evaluating the legality of a vertical agreement under competition law. Both jurisdictions emphasize the market power of the producer, but the allowed percentage of market share varies between EU and US and only EU legislation gives emphasis to the market power of the distributor. These differences in competition legislations regulating vertical agreements can lead to conflicts when interpreting the legality of a distribution agreement. The definition of relevant product markets might lead to big international multisectoral companies abusing their dominant position by entering into exclusive arrangements.
\end{abstract}

Keywords: exclusive distribution; vertical agreements; vertical restraints; non-compete; competition law

How to cite (Chicago 16th): Hanni, Noona. "Exclusive Transnational Distribution Agreements and Non-Compete Clauses in Trade Between European Union and United States." Udayana Journal of Law and Culture 3, no. 2 (2019): 141-163. https://doi.org/10.24843/UJLC.2019.v03.i02.p02.

doi: https://doi.org/10.24843/UJLC.2019.v03.i02.p02

\footnotetext{
*Email/Corresponding Author: noona.s.hanni@utu.fi
} 


\section{Introduction}

Distribution agreements can be highly international and transnational in nature, but there is no international legislation or treaty regulating vertical agreements between private parties in such. In the literature regarding distribution agreements under international law it is stated that distribution agreements are often granted "sole" or "exclusive" rights of representation. ${ }^{1}$ In an exclusive distribution agreement it is prohibited to appoint another distributor for the territory of the representative by the supplier. ${ }^{2}$ Both in European Union (EU) competition law and in United States (US) antitrust law, exclusive distribution agreements are considered as lawful restrictions on competition as long as they fulfil certain criteria. ${ }^{3}$ Distribution agreements play an important part in the internalization of trade: to ensure the sale of goods cross boarder it is important for national companies to be able to enter into exclusive distribution agreements with foreign distributors. This enables the efficient sale of goods abroad and makes it possible for even smaller national companies to expand the sale of their products across borders. Since there is no international legislation regulating transnational vertical agreements between private factors, we need to look into national legislation and case law to understand how these exclusive contracts, and in particular the non-compete clauses, are interpreted. This article will focus on exclusive distribution agreements and vertical non-compete clauses that are concluded between private companies from EU and US jurisdictions.

In EU competition law and US antitrust law the treatment of vertical restraints is somewhat different. ${ }^{4} \mathrm{EU}$ competition law recognizes the terms of block exemption and 'safe haven', whereas the US antitrust law does not regulate any exemptions to vertical restraints. Vertical restraints are interpreted in the US common law of antitrust in the light of Rule of Reason. A rule of reason requires that the plaintiff needs to plead and prove that the defendant with market power has engaged in anticompetitive conduct. There are also some fundamental differences in some definitions of terms connected to competition law. These different ways of treating vertical restraints and definitions in the US and EU legislation can cause problems when companies operating in the EU and US are entering into an exclusive distribution agreement. EU competition law recognizes non-compete clauses in vertical agreements as lawful restrictions on competition

${ }^{1}$ Carole Murray, David Holloway, Daren Timson-Hunt and Clive M Schmitthoff, Schmitthoff: The Law and Practice of International Trade. Sweet \& Maxwell, 2012, 860.

2 Ibid.

${ }^{3}$ C-56/65 - Société Technique Minière v Maschinenbau Ulm and United States v. Imperial Chern. Indust., Ltd, 1952

${ }^{4}$ James C. Cooper, Luke M. Froeb, Daniel P. O’Brien, Michael G. Vita, A Comparative Study of United States and European Union Approaches to Vertical Policy. www2.owen.vanderbilt.edu/lukefroeb/froeb.papers/vertical/2006.GMU.pdf 
under certain rules. ${ }^{5}$ However, when we look into US antitrust law and case law we soon discover that non-compete clauses as vertical restraints are not recognized as such in US legislation.

There have been some previous literatures that almost have a similar topic of the present article. Incardona analyzed the EC competition rules applicable to distribution agreements, with an eye to the European case-law, economic analysis and comparing with the US antitrust experience. ${ }^{6}$ Gajin studied how EU and US antitrust laws assess the legality of exclusive distribution agreement and evaluated the extent of these two legal systems can be seen compatible with the economic theory of exclusive territories. ${ }^{7}$

Another comparative study can be seen in the work of Chernobrovkin that focuses its analysis on the distribution agreements, both for the civil and the public legal framework (competition law) by comparing the legal frameworks on distribution and agency agreements in the European Union and in the Russian Federation. ${ }^{8}$

Macedo studied the distribution agreements in an online context that covers the discussion on vertical restraints and Block Exemption Regulation dispose, ${ }^{9}$ while Iacobucci and Winter observed EU competition law on vertical restraints in a specific area of distribution over the internet. ${ }^{10}$ Raad inquiried the effectiveness of EU competition policy and law and found that the Commission and the European Court of Justice do not fully agree on the approach EU competition law should have. ${ }^{11}$

This article analyzes the differences in legislation of vertical restraints in the EU and the US, and looks at the case law to find out how these transnational agreements are compatible under the competition law of both countries. Bearing in mind the legal framework regulating vertical restraints, the issue also will be addressed from an economic perspective. Exclusive distribution agreements

5 Comissions Regulation (EU) No 330/2010 of 20 April 2010 on the Application of Article 101(3) of the Treaty on the Functioning of the European Union to Categories of Vertical Agreements and Concerted Practices (Block Exemption Regulation), Art. 5

${ }^{6}$ Rossella Incardona, "Distribution Agreements under EC Competition Law." Available at SSRN 1185371 (2005): 12-33

7 Dragan Gajin, "Antitrust Aspects of Exclusive Distribution Agreements" (Dissertation of Doctor of Juridical Science, Central European University Department of Legal Studies, Budapest, 2011), ii. www.etd.ceu.hu/2011/gajin_dragan.pdf

8 Alexander Chernobrovkin, "International Distribution and Agency Agreements in Russian Law and Practice in Comparison to the European Approach" (Master Thesis, Advanced Studies in European Law, Ghent University Law School, July 2011), 6.

9 Inês Silva Macedo, "Distribution Agreements: Ban on Internet Sales-Towards a More Economic Based Approach" (Master Thesis, Portuguese Catholic University Faculty of Law, Oporto School, May 2017),

https://repositorio.ucp.pt/bitstream/10400.14/23296/1/Master's\%20Thesis\%20-

\%20In\%C3\%AAs\%20Macedo.pdf

10 Edward Iacobucci and Ralph A. Winter, European Law on Selective Distribution and Internet Sales: An Economic Perspective, Antitrust Law Journal 81 (2016): 47.

11 Puya Raad, Effectiveness of EU Law and Policy on Vertical Restraints at Protecting Competition." Wroclaw Review of Law, Administration \& Economics 3, no. 1 (2013): 119-125. https://doi.org/10.2478/wrlae-2013-0047 
between non-dominant firms are often considered to increase efficiency and thus competition and economic welfare both under EU and US legislation. ${ }^{12}$ However, as will be seen later in this article, the definition of relevant markets in exclusive distribution can lead to the abusive use of their dominant position by big multisectoral companies. This article focuses on the following legal and economic questions: how do the competition legislations regulating vertical agreements differ in EU and US and what kind of effect can transnational exclusive arrangements and non-compete clauses have on the efficiency of international trade? This issue is highly relevant in light of the constant internationalization of trade and the increasing growth of e-commerce.

It should be acknowledged that this article further develops previous publication written by the Author, 13 that has been modified.

\section{Result and Analysis}

\subsection{Distribution Agreements in International Trade}

\subsubsection{Imports and Exports as Part of International Trade}

The interaction between exporting and importing firms is at the center of international markets. ${ }^{14}$ In this context, exporters can be seen as manufacturers and importers as distributors. Selling products to the final consumers involves production and distribution, and especially when exporting firms are engaging in international trade they must find distributors in order to enter foreign markets. This can be considered a costly activity, and these search costs can be seen as a barrier to international trade and can lead to fixed prices in exporting. ${ }^{15}$ However, without these kind of distribution arrangements small national companies could not engage in international trade. Since markets are nationally regulated and dominated by local intermediaries, companies expanding their sales abroad need to make agreements with local distributors to benefit from their knowledge of their own markets. ${ }^{16} \mathrm{~A}$ distribution sector that stands between manufacturers and final consumers has implications for the magnitude of trade flows on an international level. ${ }^{17}$

\subsubsection{Exclusive Distribution: Free Trade Against Fair Competition}

12 Microsoft, 253 F.3d at 58 and Green Paper on Vertical Restraints in EC Competition Policy 1997, para 59

13 Previous research carried out by Author. Noona Hanni, "Exclusive Transnational Distribution Agreements and Non-Compete Clauses in Trade Between EU and US" (Bachelors Thesis, University of Turku, Faculty of Law, 2019).

${ }^{14}$ Felipe Benguria, Production and Distribution in International Trade: Evidence from Matched Exporter-Importer Data. Job Market Paper 2013. 2.

15 Ibid., 3.

16 David Arnold, , Seven Rules of International Distribution, Harvard Business Review November-December 2000 issue.

www.hbr.org/2000/11/seven-rules-of-international-distribution

17 Felipe Benguria. op.cit., 4. 
Vertical restraints, in general, are not regarded as suspicious per se or necessarily pro-competitive. ${ }^{18}$ When looking at exclusive distribution agreements in light of the principles of free trade, it appears that these agreements are contrary to the objectives of free trade. The principle of free trade means, basically, the elimination of all artificial trade barriers to the exchange of products across national markets. ${ }^{19}$ Exclusive distribution agreements cause territorial exclusivity, lead to artificial prices and cause artificial barriers that foreclose markets to new entrants and, therefore, cannot be accommodated into the principles of free trade. ${ }^{20}$ As non-compete clauses create an artificial barrier to trade they also fall outside the basic principles of free trade.

The ability to enter into an exclusive distribution agreement can be regarded as crucial for small and medium-size companies planning to enter into international markets or expand cross borders. Exclusive agreements often benefit both the supplier and distributor: it is more efficient for the supplier to focus the distribution of their products on one distributor in a certain area. This way the distributor can invest in the distribution of its products and does not have to worry about possible 'free riders'. Exclusive distribution increases the efficient distribution across borders and reduces transaction costs but can also decrease intra-brand competition between distributors. Intra-brand competition is competition among retailers or distributors of the same brand. ${ }^{21}$ Anticompetitive effects are only likely to occur when inter-brand competition is weak and there are barriers to entry at the producer or distributor level. ${ }^{22}$

\subsubsection{Defining Relevant Markets: Abuse of Dominant Market Position}

In order to understand how distribution agreements can lead to anticompetitive effects and therefore affect international markets, it is important to understand the terms 'relevant market' and 'abuse of dominant market position'. When defining the concept of relevant markets in EU law significance is given both to product markets and geographical markets. In the relevant Commissions Notice, ${ }^{23}$ these terms are defined explicitly: 'A relevant product market comprises all those products and/or services which are regarded as interchangeable or substitutable by the consumer, by reason of the products' characteristics, their prices and their intended use'. 'The relevant geographic market comprises the area in which the undertakings concerned are involved in the supply and demand of products or services, in which the conditions of competition are sufficiently

\footnotetext{
18 Green Paper on Vertical Restraints in EC Competition Policy (10)

${ }_{19}$ Mervyn Martin, "'Sole distribution agreements in the context of the general principles of free trade and competition." Syracuse J. Int'l L. \& Com. 35 (2007), 81.

20 Ibid., 81-82.

21 OECD. Glossary of Statistical Terms. www.stats.oecd.org/glossary/detail.asp?ID=3153

${ }^{22}$ Green Paper on vertical Restraints in EC Competition Policy, Loc Cit

${ }^{23}$ Commission Notice on the definition of relevant market for the purposes of Community competition law $(97 /$ C $372 / 03)(7-8)$
} 
homogeneous and which can be distinguished from neighbouring areas because the conditions of competition are appreciably different in those areas'.

The European Commission ('EC') has also defined the term 'abuse of dominant market position': Dominant position is not by itself anti-competitive, but if a company misuses its position to eliminate competition it is regarded as abuse of dominant position. Examples of this kind of behavior are charging unreasonably high prices or making the sale of one product conditional on the sale of another product. ${ }^{24}$ Also, US antitrust law prohibits unfair methods of competition. ${ }^{25} \mathrm{EU}$ and US regulations might appear to efficiently prohibit anticompetitive behavior that could affect trade on a national and an international level, but there are some loopholes that might lead to a big multinational company to abuse its dominant market position and get away with it. This has much to do with the definition of product markets discussed above.

When taking into consideration big multisectoral companies that operate in a number of different product markets it becomes much more difficult to identify the abuse of dominant market position. One example of a big multisectoral company like this is Nestlé. ${ }^{26}$ Nestlé manufactures different food products and beverages and is the second largest owner of cosmetics brand L'Oréal. As we can see from the definition of product markets given by the EC, food products, in general, do not constitute one relevant market, but the product markets need to be more specifically specified. The case of Hoffman-La Roche and Co $v$ Commission $^{27}$ from 1979 also supports this interpretation. In this case, the court held that different vitamins did not constitute a single market but that each type of vitamin constituted a separate market. The court held that the concept of relevant market implies that there can be effective competition between the products which form part of that market. 28

When we take this interpretation into consideration, it might lead to that a big company operating in different product markets might enter into exclusive distribution agreements or any other actions considered as vertical restrictions on competition in allegedly all of these product markets. This is possible under competition law if the market share of the company in that specific product and geographic market does not exceed the level set out in competition legislation regulating vertical restraints. This might lead, therefore, to the hidden abuse of dominant market position and have a significant impact on international trade.

24 European Commission. Delivering for Consumer: Abuse of A Dominant Position. http://ec.europa.eu/competition/consumers/abuse_en.html

25 Section 5 of the Federal Trade Commission (FTC) Act, 15 USC section 45

26 Société des Produits Nestlé S.A.

27 Hoffman-La Roche and Co $v$ Commission Case 85/76 ECJ

28 Ibid., para 28. 


\subsection{Exclusive Distribution in European Union Law}

\subsubsection{Exclusive Distribution Agreements}

A distribution agreement is a vertical agreement between a supplier and a distributor. In EU law, vertical agreements are defined in Article 2.1 of the Block Exemption regulation as agreements that are concluded between two or more undertakings operating, in the context of the agreement, at different levels in the production or distribution chain; and that are related to the purchase, sale or resale of goods or services. This definition also covers supply and distribution agreements related to goods and services. ${ }^{29} \mathrm{~A}$ distribution agreement is exclusive when the supplier agrees to supply products only to one distributor within a certain territory or to a certain group of customers. ${ }^{30}$ It is important to note that under EU law exclusive distribution agreements are often held to be lawful, mainly because of their vertical nature: if there is a distribution agreement concluded between two horizontal competitors it may be considered as horizontal cartel or illegal share of relevant markets. ${ }^{31}$ In EU law distribution agreements fall within the scope of Article 101 of the Treaty on the Functioning of the European Union. Article 101 applies to vertical agreements that may affect trade between the Member States and that prevent, restrict or distort competition. ${ }^{32}$ However, the provisions of paragraph 1 of Article 101 may be declared inapplicable in the case of an agreement between undertakings which contributes to improving the production or distribution of goods or promoting technical or economic progress, while allowing consumers a fair share of the resulting benefit. ${ }^{33}$ Distribution agreements often fall within the scope of Article 101(3) and are, therefore, within the scope of the Block Exemption, which is discussed below.

\subsubsection{Block Exemption Regulation (330/2010)}

When determining the legality of an exclusive distribution agreement in EU competition law we need to consider The Block Exemption Regulation (330/2010) passed by the EC to find the rules regulating these agreements. ${ }^{34}$ Block Exemption Regulation provides a 'safe haven' to certain vertical agreements ${ }^{35}$ and grants an exemption under Article 101(3) to restrictions of competition contained

${ }^{29}$ Ivo Van Bael and Jean-Francois Bellis (Van Bael \& Bellis (Firm). Competition law of the European Community. (Kluwer Law International cop., $5^{\text {th }}$ edition) 2010. 186.

30 Hesselink, Martijn W., Jacobien W. Rutgers, Odavia Bueno Diaz, Manolo Scotton, and Muriel Veldman. Commercial agency, franchise and distribution contracts. Walter de Gruyter, 2009.

31 Kirsi Leivo, Timo Leivo, Hannele Huimala and Mikko Huimala, EU:n ja Suomen kilpailuoikeus. (2. uudistettu painos. Talentum) 2012.

32 Guidelines on Vertical restraints, 2010/C 130/01 (5)

33 Treaty on the Functioning of the Eropean Union 101(3)

34 See Slaughter and May. the EU Competition Rules on Vertical Agreements. https://www.slaughterandmay.com/media/64575/the-eu-competition-rules-on-verticalagreements.pdf

35 Richard Whish and David Bailey, Competition Law. 7th edition. Oxford University Press 2012. 629. 
in vertical agreements. ${ }^{36}$ Such an exemption means that the vertical agreements fall outside the scope of Article 101(1) and are thus allowed in EU competition law unless they contain certain forbidden restrictions. ${ }^{37}$ It is important to note that, usually, Block Exemption does not apply to vertical agreements between 'competing undertakings' unless they enter into a non-reciprocal vertical agreement. ${ }^{38}$

However, most vertical agreements fall within the scope of the Block Exemption Regulation and will thus be block exempted: agreements will be exempted from Article 101(1) if the supplier's or buyer's market share does not exceed 30 per cent of the relevant market in which it sells the contract goods or services. This is called the market share test. This requirement applies throughout the agreements duration, not only at the time the agreement is entered into. ${ }^{39}$ Using the market share test to determine the application of vertical agreements, Block Exemption reflects that only vertical restraints engaged in by firms with a certain degree of market power pose a significant threat to competition. ${ }^{40}$

The second requirement for Block Exemption to apply is that the agreement does not include any 'hard core' restrictions defined in Article 4 of Block Exemption regulation. ${ }^{41}$ Article 5 of the same regulation sets out some excluded restrictions where the exemption also does not apply. Article 5 concerns specific obligations in vertical agreements. However, there are some exceptions to these excluded restrictions that do not cause these obligations in vertical agreement to fall out of the block exemption and the 'safe haven' as such. These exceptions are also known as non-compete obligations.

\subsubsection{Non-Compete Obligations}

The Block Exemption Regulation sets out specific rules for non-compete obligations. Article 5(1) of the Block Exemption Regulation states that the exemption provided in Article 2 shall not apply to any direct or indirect noncompete obligation, the duration of which is indefinite or exceeds five years. A non-compete obligation which is tacitly renewable beyond a period of five years shall be deemed to have been concluded for an indefinite duration. Article 5(2) includes an exception to this 5-year rule; the time limitation of five years shall

36 Ivo Van Bael and Jean-Francois Bellis, op.cit., 185.

37 Block Exemption Regulation, Art. 2

38 Ibid.

39 Ivo Van Bael and Jean-Francois Bellis, op.cit., 190.

40 Ibid.

${ }^{41}$ Richard Whish and David Bailey, loc.cit. An example of a hard core restriction listed in Article 4: restriction of the buyer's ability to determine its sale price, without prejudice to the possibility of the supplier to impose a maximum sale price or recommend a sale price, provided that they do not amount to a fixed or minimum sale price as a result of pressure from, or incentives offered by, any of the parties; 
not apply where the contract goods or services are sold by the buyer from premises and land owned by the supplier or leased by the supplier from third parties not connected with the buyer, provided that the duration of the noncompete obligation does not exceed the period of occupancy of the premises and land by the buyer. The definition of a non-compete obligation can also be found in the Block Exemption Regulation Article 1(1d): "a non-compete obligation means any direct or indirect obligation causing the buyer not to manufacture, purchase, sell or resell goods or services which compete with the contract goods or services, or any direct or indirect obligation on the buyer to purchase from the supplier or from another undertaking designated by the supplier more than $80 \%$ of the buyer's total purchases of the contract goods or services and their substitutes on the relevant market, calculated on the basis of the value or, where such is standard industry practice, the volume of its purchases in the preceding calendar year."

\subsubsection{Exclusive Distribution and Internet Sales}

Exclusive distributorship might lessen competition in the market of a certain good in a certain area. ${ }^{42}$ Even though the forbidden hard core -restrictions listed in Article 443 of Block Exemption Regulation apply also to exclusive agreements, there is an exception to the restriction of territory and customer groups listed in Article 4(b). This exception allows a supplier to restrict active sales by a buyer party to the agreement to a territory or a customer group. Restriction of passive sales is not allowed under this exception and the Commission has imposed

42 Kirsi Leivo, Timo Leivo, Hannele Huimala and Mikko Huimala, op.cit., 514.

${ }^{43}$ Article 4 of the Block Exemption Regulation: "The exemption provided for in Article 2 shall not apply to vertical agreements which, directly or indirectly, in isolation or in combination with other factors under the control of the parties, have as their object: (a) the restriction of the buyer's ability to determine its sale price, without prejudice to the possibility of the supplier to impose a maximum sale price or recommend a sale price, provided that they do not amount to a fixed or minimum sale price as a result of pressure from, or incentives offered by, any of the parties; (b) the restriction of the territory into which, or of the customers to whom, a buyer party to the agreement, without prejudice to a restriction on its place of establishment, may sell the contract goods or services, except: (i) the restriction of active sales into the exclusive territory or to an exclusive customer group reserved to the supplier or allocated by the supplier to another buyer, where such a restriction does not limit sales by the customers of the buyer, (ii) the restriction of sales to end users by a buyer operating at the wholesale level of trade, (iii) the restriction of sales by the members of a selective distribution system to unauthorised distributors within the territory reserved by the supplier to operate that system, and (iv) the restriction of the buyer's ability to sell components, supplied for the purposes of incorporation, to customers who would use them to manufacture the same type of goods as those produced by the supplier; (c) the restriction of active or passive sales to end users by members of a selective distribution system operating at the retail level of trade, without prejudice to the possibility of prohibiting a member of the system from operating out of an unauthorised place of establishment; (d) the restriction of cross-supplies between distributors within a selective distribution system, including between distributors operating at different level of trade; (e) the restriction, agreed between a supplier of components and a buyer who incorporates those components, of the supplier's ability to sell the components as spare parts to end-users or to repairers or other service providers not entrusted by the buyer with the repair or servicing of its goods. 
notable fines on firms breaching this restriction. ${ }^{44}$ The terms of active and passive sales are defined exclusively in Vertical Guidelines. ${ }^{45}$

Clauses in vertical agreements restricting the use of internet sales affect directly to which areas and to which customer groups the distributor is allowed to sell. ${ }^{46}$ The Commission has defined explicitly in Vertical Guidelines when the restriction of internet sales is considered to be an unlawful restriction of passive sales. In principle, every distributor must be allowed to use the internet to sell products. In general, where a distributor uses a website to sell products that is considered to be a form of passive selling. If a customer visits the web site of the distributor and contacts the distributor and that contact leads to a sale, then it is considered passive selling. The same is true if a customer wishes to be kept automatically informed by the distributor and it leads to a sale. ${ }^{47}$

\subsubsection{Exclusive Distribution and Non-Compete}

Exclusive distribution agreements are not illegal per se under Article 101 of the Treaty on the Functioning of the European Union (TFEU) ${ }^{48}$. In Vertical Guidelines the EC has stated that exclusive distribution is exempted when both the buyer and the supplier pass the market share test, even when combined with a non-compete obligation limited to five years. ${ }^{49}$ An exclusive distribution agreement containing a non-compete clause after the termination of the agreement, which prevents the distributor from participating in manufacturing, purchasing, selling or reselling, is not permitted unless this prohibition relates to competing products and is limited to the premises from where the distributor operated during the term of the agreement. It can also cover the know-how transferred from the manufacturer to the distributor. These post-term noncompete clauses are limited to a one-year duration. The restriction can also be unlimited to prevent disclosure of know-how that has not yet entered the public domain. 50

\subsection{Distribution under United States Antitrust Law}

\subsubsection{Vertical Restraints}

US antitrust law differs from EU competition law and that causes some legal challenges in the interpretation and validity of distribution agreements between private companies from EU and US jurisdictions. The basis of US antitrust law lies in the Sherman Antitrust Act from 1890. Section 1 of that act is most often

${ }^{44}$ Commissions Decision 2003/675 Nintendo

45 Vertical Guidelines, para 51

46 Kirsi Leivo, Timo Leivo, Hannele Huimala and Mikko Huimala, EU:n ja Suomen kilpailuoikeus. (2. uudistettu painos. Talentum) 2012. 519.

47 Vertical Guidelines, para 52

48 C-56/65 - Société Technique Minière v Maschinenbau Ulm

49 Vertical Guidelines, para 152

50 Block Exemption Regulation, Art. 5 
cited in cases regarding vertical restraints. Section 1 prohibits 'every contract, combination in the form of trust or otherwise, or conspiracy, in restraint of trade'. ${ }^{51}$ One other important act regulating competition in the US is the Clayton Act. Section 3 of the Clayton Act prohibits the selling of goods on the condition that the purchaser refrains from buying a competitor's goods if it may lead to substantially lessened competition. ${ }^{52}$ The Federal Trade Commission Act, section 5 , applies to vertical restraints as well. Section 5 declares unlawful unfair methods of competition. However, US courts have for a long time treated antitrust as a common law field. 53

Vertical restraints are not expressly defined in US law. The common law of antitrust needs to be considered to find out what the courts have held to be vertical restraints. Unlike the EU jurisdiction, US antitrust law does not regulate either any specific block exemptions or safe havens.

\subsubsection{Exclusive Dealing under United States Antitrust Law}

Exclusive distribution agreements are not illegal under US antitrust law. ${ }^{54}$ Exclusive agreements can be necessary to prevent retailers and rival manufacturers from free-riding off of a supplier's direct investments. ${ }^{55}$ In the absence of monopolization, a US manufacturer may appoint an exclusive distributor for one foreign country or a part of a country with only a few antitrust consequences. This interpretation arises from the fact that, domestically, a US company can engage in such conduct. ${ }^{56}$ The Bausch and Lomb Optical case ${ }^{57}$ is a leading case when it comes to interstate commerce and exclusive dealing. In this case, the Supreme Court upheld an arrangement where the Soft-Lite Company became the sole distributor of Bausch \& Lomb products, and Bausch \& Lomb agreed not to sell their products to other competitors or to compete with Soft-Lite. In the Schwinn case 58 the court reaffirmed that a manufacturer may grant an exclusive territory to a distributor and agree not to compete with them or to appoint any other distributor to the area. The case held that this is permissible "if competitive products are already available to others". 59 In contrast to this expansive interpretation when it comes to restrictions upon distributors,

51 Joel Mitnick, Karen Katzmerzak, Peter K Houston, Vertical Agreements United States.

Sidley Austin LLP. www.gettingthedealthrough.com/area/41/jurisdiction/23/verticalagreements-2017-united-states/

5215 USC, section 14 (2012)

${ }^{53}$ Frank H Easterbrook, Vertical Arrangements and the Rule of Reason: Antitrust Law Enforcement in the Vertical Restraints Area.

${ }^{54}$ United States $v$. Imperial Chern. Indust., Ltd, 1952

55 James C. Cooper, Luke M. Froeb, Daniel P. O’Brien, Michael G. Vita, op.cit.

56 Wilburg L. Fugate, International Distribution Agreements. Antitrust Law Journal 43 (1974), 541.

57 United States $v$ Bausch and Lomb Optical Co, 321 U.S 707 (1944)

58388 US 365 (1967)

59 Ibid. 
exclusive purchase requirements do not have the same effects when applied to a foreign distributor but may have antitrust aspects if US commerce is affected. 60

When trying to understand transnational exclusive distributorship in the context of US antitrust law the most important question is whether a US manufacturer may restrict the sales area of a foreign distributor. Schwinn and other US cases have laid down the general rule: restrictions upon the territory of resale by a purchaser are illegal even if manufacturers may prescribe exclusive territories for distributors. ${ }^{61}$

The restrictions imposed by a US company on a foreign distributor not to sell in other countries would not seem to have the required substantive effect on US commerce and would thus appear not to be a violation of US antitrust laws. ${ }^{62}$ This said, a US manufacturer needs to consider the national laws of the country in which the distributorship arrangement operates.

\subsubsection{Rule of Reason}

US courts evaluate most antitrust claims under a 'rule of reason'. A rule of reason requires that the plaintiff needs to plead and prove that the defendant with market power has engaged in anticompetitive conduct. ${ }^{63}$ In recent years most vertical restraints cases have been analyzed under the rule of reason. The US Supreme Court's approach towards vertical restraints, in general, has been unanimous. ${ }^{64}$ In Continental TV Inc $v$ Sylvania Inc. the Court held that the rule of reason should apply to vertical non-price restraints as they might restrict intrabrand competition. ${ }^{65}$ The rule of reason analysis begins with two steps: first, the examination of the nature of the relevant agreement, and secondly, whether it has caused or is likely to cause anticompetitive harm. The main question to be considered is whether the agreement has or is likely to create or increase market power or facilitate its exercise. Weighing the reasonableness of the agreement and the pro-competitive benefits against the harm to the competition are the essential aspects of the rule of reason. If the pro-competitive benefits outweigh the harm to competition, the agreement is most likely to be deemed lawful under the rule of reason. ${ }^{66}$ In deeming the unreasonable restrictions as violations to US antitrust law a major criterion is the market power of the producer. ${ }^{67}$ The market share analysis used in the US by the courts to determine the market power of the

60 Wilburg L. Fugate, op.cit., 542.

${ }^{61}$ Ibid.

62 Ibid.

${ }^{63}$ Areeda Hovenkamp and Herbert Hovenkamp, Antitrust Law: An Analysis of Antitrust Principles and Their Application, 4th edition 2017.

${ }^{64}$ Mervyn Martin, op.cit., 91.

65 Cont'l TV v GTE Sylvania Inc. 433 US 1977

66 Patrick J Harrison, Vertical Agreements. Law and Business Research, 2018. www.sidley.com/-/media/publications/va2018usa.pdf

67 Valley Liquors Inc, $v$ Renfield Imps. Ltd., 678 F.2d 742, 745, 7th Cir. 1982 
producer has not always been consistent. 68 In Graphic Products Distributors, Inc. $v$. Itek Corporation ${ }^{69}$ the court held that $70-75 \%$ of market share constitutes market power whereas in Rothery Storage \& Van Co. v. Atlas Van Lines, Inc., ${ }^{70}$ the court held that market share of $20-25 \%$ or less does not constitute market power. However, in Domed Stadium ${ }^{71}$ "the lowest possible market share legally sufficient to sustain a finding of monopolization was between $17 \%$ and $25 \%$." In all these cases the definition of relevant geographic market was crucial when determining the percentages.

\subsubsection{Exclusive Dealing and Rule of Reason}

Exclusive dealing agreements may harm competition by foreclosing competitors of the supplier from marketing their products to that buyer. Exclusive dealing is subject to challenge under US antitrust law. These arrangements have not been considered unlawful per se, and, therefore, such conduct is analyzed by the courts under the rule of reason. The most important factors in this analysis are the percentage of commerce foreclosed within a properly defined market and the anticompetitive effects of such foreclosure. Exclusive dealing arrangements do not raise competitive concerns under US antitrust law per se: a plaintiff needs to show that they are likely to have a net deleterious effect on competition. ${ }^{72}$ In cases like this, the share of the downstream market covered by exclusive contracts serves a deal breaking function; if the percentage of the market covered is small, the success rate for the plaintiff is typically also small. ${ }^{73}$ Even if plaintiffs are able to prove substantial foreclosure, they must show in addition that the defendant's agreements are likely to result in prices above the competitive level. ${ }^{74}$ It is on the plaintiff to prove that the market share covered by the contract is big enough to lead to foreclosure and that it results in prices above the competitive level. 75

An important case in the US concerning the legality of exclusive dealing arrangements is Microsoft, 253 F.3d at 58. As was stated in the case from United States Court of Appeal, the ability to distinguish between pro and anticompetitive vertical restrictions is not easy in practice and continues to be a central focus of antitrust scholarship, yet it is an important matter when we look at the exclusive dealing arrangements in the light of rule of reason. In this case it was noted that "[ $\mathrm{t}]$ he challenge for an antitrust court lies in stating a general rule for distinguishing between exclusionary acts, which reduce social welfare, and

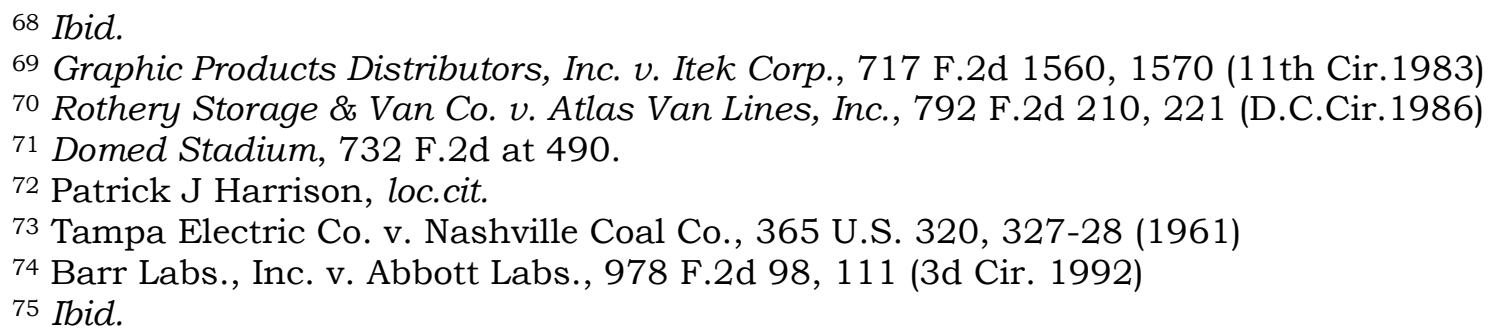


competitive acts, which increase it." 76 In Apani Southwest, Inc. v. Coca-Cola Enterprises ${ }^{77}$ the US Supreme Court explained the analysis of the landmark case of Tampa Electric. Co. v. Nashville Coal $\mathrm{Co}^{78}$ regarding the legality of exclusive dealing under US antitrust law. The Court explained that when evaluating whether an exclusive dealing agreement has the probable effect of substantially lessening competition, a three-part inquiry needs to be undertaken.

First, the relevant product market must be identified by considering interchangeability and cross-elasticity of demand. Second, the relevant geographic market must be identified, by careful selection of the market area in which the seller operates and to which the purchaser can practicably turn for supplies. Finally, a plaintiff must show that the competition foreclosed by the arrangement constitutes a substantial share of the relevant market. That is, the opportunities for other traders to enter into or remain in that market must be significantly limited.

\subsubsection{Non-compete Clauses in United States Legislation}

In exclusive dealing arrangements, the buyer is required to purchase products or services for a certain period of time from one supplier. These kind of exclusive agreements can involve a prohibition on the buyer to purchase from the supplier's competitors, or a requirement committing the buyer to purchase all, or a substantial portion, of its total requirement of specific goods or services only from that supplier; in other words a direct or an indirect non-compete clause. ${ }^{79} \mathrm{~A}$ doctrine that the courts in the US apply to non-compete clauses is called the 'blue pencil rule'. The blue pencil rule is a legal doctrine used in the common law countries where a court finds part of a contract void but leaves the other parts enforceable. Courts in the United States seem to be divided when it comes to the application of this doctrine. ${ }^{80}$ Some courts apply this doctrine to overly restrictive non-compete clauses rendering them null and void, whereas other courts merely modify these clauses into an enforceable less restrictive, clause. ${ }^{81}$ Like exclusive dealing arrangements, non-compete clauses are generally evaluated under the rule of reason. ${ }^{82}$

Interestingly, in recent years in the state of Michigan, the Michigan Supreme Court gave its decision in Innovation Ventures $v$. Liquid Manufacturing. ${ }^{83}$ The

76 Microsoft, 253 F.3d at 58

77300 F.3d 620, 625 (5th Cir. 2002)

78365 U.S. 320, 327-28 (1961)

79 Joel Mitnick, Karen Katzmerzak, Peter K Houston, loc.cit.

80 Filip De Ly, "Non-Compete Clauses in International Contract-Les Clauses de NonConcurrence Dans Les Contrats Internationaux." Int'l Bus. LJ (2006): 458.

81 Ibid

82 Miller Canfield. Michigan Supreme Court Makes Commercial Non-Compete Agreements Easier to $\quad$ Enforce. www.millercanfield.com/newsletter478.html?click_source=sitepilot07!2718!c3VibWlzc2lvbnNAbGV4b2xvZ3kuY29t

${ }^{83}$ Innovation Ventures LLC v. Liquid Manufacturing LLC, 315519 (Mich. Ct. App. 2014) 
court held that commercial non-compete agreements are enforceable so long as they satisfy the Michigan Antitrust Reform Act. This means that commercial noncompete agreements no longer need to satisfy the common law "balancing test" under the rule of reason. The Innovation Ventures case thus eliminates consideration of the non-competes effect on the restrained party unless it impacts the overall market. ${ }^{84}$ This judgement applies only in the state of Michigan, but it is a good example of the development of common law around antitrust in the US.

\subsection{Transnational Distribution Agreements between European Union and United States \\ 2.4.1. Vertical Restraints in Foreign Trade in European Union and United States}

Previous sections have addressed the basic rules regulating exclusive distribution and non-compete clauses in the EU and the US. As has been noted, there are substantial differences in the antitrust legislation in both jurisdictions. EU law regulates precisely the framework in which an exclusive distribution agreement, including a non-compete clause, is regarded as lawful, whereas US antitrust law leaves open the question and analyses specific cases under the rule of reason. The US antitrust law highlights the percentage of markets foreclosed and the weighing between actual anti-competitive and pro-competitive effects, whereas EU legislation relies on the market share test and the list of hard-core restrictions. The US antitrust law is formulated in the interest of US consumers, so when a US company engages in trade with foreign companies and consumers they can soon discover that the US antitrust law regulating domestic affairs may not apply to foreign trade. Such companies need to take into consideration foreign national competition regulations to avoid being in breach of the relevant law. 85 In comparison, EU competition legislation is formulated to ensure free trade in the single market.

In the US, the plaintiff is obligated to show that a vertical agreement is likely to harm competition and reduce economic welfare, whereas EU competition law places a lower burden on the EC. EU law condemns many more vertical agreements than the US antitrust law and the treatment under EU law is harsher. 86 Even though both EU and US jurisdictions share the same beliefs regarding the theoretical and empirical effects of vertical restraints, the differences in treatment of vertical restraints can be explained by different loss functions. ${ }^{87}$

84 Miller Canfield, loc.cit.

85 Wilburg L. Fugate, op.cit., 541.

86 James C. Cooper, Luke M. Froeb, Daniel P. O’Brien, Michael G. Vita, op.cit.

87 Ibid, 290. 


\subsubsection{Jurisdiction and Choice of Law}

When it comes to the jurisdiction and choice of law when interpreting transnational distribution agreements, it is important to keep in mind the basic principle of freedom of contract. According to Regulation (EC) No 593/2008 of the European Parliament and of the Council of 17 June 2008 on the law applicable to contractual obligations, also known as Rome I, previously known as the Rome Convention, the parties to a distribution agreement are free to choose the law applicable to the contract. ${ }^{88}$ If the applicable law is not explicitly stated in the contract, Article 4(1) of Rome I will be applied; a distribution contract shall be governed by the law of the country where the distributor has his habitual residence. Of course, this rule only applies to members of the treaty, which includes most EU countries.

Even though the choice of law is up to the parties to the contract, it is important to remember that the national competition laws will always regulate vertical restraints. This is why it is important to understand the national competition regulation applying to all of the parties involved in a distribution agreement.

One interesting case from Court of Appeal in the United Kingdom regarding the applicable law governing a termination of self-employed commercial agency contracts is Ingmar GB Ltd $v$ Eaton Leonard Technologies Inc. 89 This case dealt with the applicability of Directive 86/653 on the coordination of the laws of the Member States relating to self-employed commercial agents, which guarantee certain rights to commercial agents after the termination of agency contracts. The court ruled that the directive must be applied where the commercial agent carried on his activity in a Member State, although the principle was established in a non-member country and a clause of the contract stipulated that the contract was to be governed by the law of that country. Parties to the contract were established in the United Kingdom and California. A clause of the contract stipulated that the contract was governed by the law of the State of California. In the case, it was agreed that "the freedom of contracting parties to choose the system of law by which they wish their contractual relations to be governed is a basic tenet of private international law and that that freedom is removed only by rules that are mandatory." However, in this case, the court held that it is essential for the European Community legal order that a principal established in a non-member country, whose commercial agent carries on his or her activity within the Community, cannot evade those provisions by the simple expedient of a choice-of-law clause; the directive must thus be applied. Although the directive, in this case, concerned agency contracts, the case is of importance when

88 Regulation (EC) No 593/2008 of the European Parliament and of the Council of 17 June 2008 on the Law Applicable to Contractual Obligations

${ }^{89}$ Case C-381/98 be [2001] 1 All ER (Comm) 329 
evaluating the applicability of law in commercial contract cases between EU and US.

\subsubsection{Exclusive Distribution between European Union and United States}

Exclusive distribution agreements are generally compatible with competition both in the EU and the US regimes. The rule of reason in the US and the Block Exemption Regulation in EU both seek to regulate the effects of exclusive distribution agreements in relation to the competitive process. 90 One reason for this could be the need to address the increasing transnational effects of anticompetitive practices. ${ }^{91}$ In the US, exclusive dealing arrangements where the distributor is required to take all or part of his requirements from one supplier have limited antitrust significance when it comes to foreign suppliers and customers. Most cases dealing with exclusive distributorship in the US are challenged under Section 3 of the Clayton Act, but this act only applies where goods are sold or leased "for use, consumption or resale within the United States". This provision applies to US imports but does not apply to the sale of goods in US export trade or for resale abroad. ${ }^{92}$ As can be seen in the wordings of different legislation, the obligations of a distributorship sometimes rest on different parties. Some authors ${ }^{93}$ argue that the obligations lie on the supplier, the others ${ }^{94}$ that they lie on the distributor. However, exclusive distribution agreements can be regarded benefiting both parties of the agreement. ${ }^{95}$

\subsubsection{Non-Compete Clauses in International Commercial Agreements}

Non-compete clauses in international transactions often raise competition law issues even in vertical relationships. Antitrust laws determine the regulatory framework under which the validity of non-compete clauses is to be determined, and thus it is important to keep these national competition regulations in mind when drafting such clauses in international contracts. ${ }^{96}$ In addition to national competition laws, uniform law and self-regulation also can impact the validity of a non-compete clause in international agreements. For example, the International Chamber of Commerce (ICC) has set out model contracts which contain noncompete clauses for commercial distributorship. 97 However, when it comes to non-compete clauses in distribution agreements, self-regulation has a much

\footnotetext{
90 Mervyn Martin, op.cit., 92.

91 Ernst-Ulrich Petersmann, "International Competition Rules for Governments and for Private Business." Journal of World Trade 30, no. 3 (1996): 12-13.

92 Wilburg L. Fugate, op.cit., 544

93 Barry Rodger and Angus A MacClulloch, Competition Law and Policy in the European Community and the United Kingdom. Cavendish Publishing Ltd, 3rd edition. 2001.

94 Joanna Goyder, EU Distribution Law. (5th edition. Hart Publishing) 2011. 171-172.

95 Ibid.

96 Filip De Ly, op.cit., 444.

97 Ibid., 445.
} 
stronger impact since the official uniform law only regulates self-employed agents and franchise agreements. 98

There are some important distinctions between legal systems regarding the validity of non-compete clauses, thus the question of which law applies to the non-compete clause might be important. ${ }^{99}$ There might be a tension between the law governing the contract and the mandatory national rules of the other national legal system governing restrictions regarding non-compete clauses. ${ }^{100}$ General contract law in both common and civil law jurisdictions does not contain specific statutory provisions dealing with non-compete clauses, but the legal tradition is often derived from other statutory provisions, general principles of law or from case law, of course with some exceptions. ${ }^{101}$ National rules vary from country to country, which creates challenges when determining the validity of a noncompete clause in international commercial contracts.

\section{Conclusion}

US companies have been involved in proceedings before the EC involving prohibitions upon parallel import within the single market. ${ }^{102}$ When we talk about distribution agreements in cross border trade, we are principally talking about arrangements with foreign companies for the sale and export of goods from one country to another. ${ }^{103}$ This applies also in trade between EU and US companies. While antitrust and competition principles abound both in the US and abroad, the international aspects are not often treated separately. As we know from the case law, US antitrust acts apply to foreign commerce only in limited circumstances.

Competition law has traditionally been regarded as a national field of law and vertical restraints are regulated on a national level, even though the EU legislation has formulated certain criteria and obligations in restraints affecting trade between the Member States. In transnational distribution, we need to take into account the possible differences in national legislation. As this article shows, there are some differences in the legislative regime of vertical restraints in EU and US, but the basic principles are the same. Both regimes place emphasis on the market power of the producer. ${ }^{104}$ However, only EU law seems to emphasize the market power of the distributor. When evaluating the legality of an exclusive distribution agreement under both EU and US legislation, consideration needs to be given to the market power of the contracting parties, the percentage of markets foreclosed and the relevant markets the parties are operating in. The geographic

\footnotetext{
98 Ibid., 446.

99 Ibid., 448.

100 Ibid., 449.

101 Ibid.

102 Wilburg L Fugate, op.cit., 543.

103 Ibid., 540.

104 Mervyn Martin, loc.cit.
} 
markets defined in paragraph 2.3. play an important role when determining the legality of an exclusive distribution agreement. Under EU law, the emphasis is given to the fact that the conditions of competition are sufficiently homogeneous and the area can be sufficiently distinguished from neighboring areas in this regard. ${ }^{105}$ In the US case law, the emphasis has been given to "the market area in which the seller operates and to which the purchaser can practicably turn for supplies". 106 This different understanding of geographic markets creates problems.

From an EU perspective, there is some uncertainty when trying to predict the permissibility of exclusive distribution agreements when entering the US markets. The market share test used in EU law sets out the allowed market power of the contracting parties to a vertical agreement at $30 \%$, but in the US the question is much more complicated. The market share analysis used in the US by the courts to determine the market power of the producer has not always been consistent The case law has deemed a market share of $70-75 \%$ as significant market power and $20-25 \%$ or less as not constituting such power. However, what happens to the companies falling between these percentages is something that the courts will evaluate on a case by case basis under the rule of reason.

The evaluation of commercial non-compete clauses as vertical restraints can be somewhat more difficult given the different regulatory frameworks. The differences between legislation regarding commercial non-compete agreements in different states raises challenges to legal interpretation. The recent Innovation Ventures $v$. Liquid Manufacturing ${ }^{107}$ case seems to diminish the importance of the rule of reason as a core evaluator of non-compete clauses.

Exclusive distribution and non-compete clauses can be regarded as having both positive and negative effects on international markets. These forms of vertical restraints might be considered as artificial barriers to trade and pure competition, but they have their place in constantly growing international markets. In strong territorial markets like the EU and the US it is more important than ever to secure the entrance of smaller businesses into the markets to ensure fair competition and economic welfare, and to prevent the hidden abuse of dominant market position by big multisectoral companies which enter into distribution agreements that can be considered as restrictions on competition. Most forms of distribution still occur within national borders, but in the constant internationalization of trade, the need for transnational agreements is growing. An international treaty regulating vertical restraints in international trade is unlikely because of the long-lasting legal tradition of national competition legislations, but a bilateral treaty between dominant markets such as the US and

105 Commission Notice on the Definition of Relevant Market for the Purposes of Community Competition Law (97/C $372 / 03$ ) (8)

106 Apani Southwest, Inc. v. Coca-Cola Enterprises, 300 F.3d 620, 625 (5th Cir. 2002)

107 Innovation Ventures, LLC v. Liquid Manufacturing, LLC, No. 150591 (July 14, 2016) 
the EU could be worth considering to ensure coherent interpretation of transnational distribution agreements.

\section{Acknowledgment and Disclaimer}

This article is an advanced version of a thesis written by the same Author, University of Turku, Faculty of Law, 2019. The substance contained in this academic paper is a personal view of the author and does not necessarily connect to Author's affiliation.

\section{BIBLIOGRAPHY}

\section{Book}

Ezrachi, Ariel, EU competition law: an analytical guide to the leading cases. 2nd edition. Portland, Or: Hart Pub 2010.

Goyder, Joanna, EU distribution law. 5th edition. Hart Publishing 2011.

Henriksson, Lars, Distributionsavtal: vertikala avtal och konkurrensrättsliga aspekter. Norstedts juridik 2012.

Hesselink, Martijn W., Jacobien W. Rutgers, Odavia Bueno Díaz, Manolo Scotton, and Muriel Veldman. Commercial agency, franchise and distribution contracts. Walter de Gruyter, 2009.

Hovenkamp, Areeda, Hovenkamp, Herbert. Antitrust law: An analysis of antitrust principles and their application 4th edition, 2017.

Leivo, Kirsi - Leivo, Timo - Huimala, Hannele - Huimala, Mikko, EU:n ja Suomen kilpailuoikeus. 2. uudistettu painos. Talentum 2012.

Lencioni, Tiina - Rautpalo, Hilppa. Jälleenmyyntisopimukset: käytännön sopimuskäsikirja. Kauppakamari. 2016.

Murray, Carole, David Holloway, Daren Timson-Hunt, Clive Maximilian Schmitthoff, and Giles Dixon. The Law and practice of international trade. Sweet \& Maxwell, 2012.

Rodger, Barry, MacClulloch, Angus A, Competition Law and Policy in the European Community and the United Kingdom, 3rd edition. Cavendish Publishing Ltd, 2001.

Van Bael, Ivo - Bellis, Jean-Franc,ois; Van Bael \& Bellis (Firm). Competition law of the European Community. 5th edition. Kluwer Law International cop. 2010.

Whish, Richard - Bailey, David, Competition Law. 7th edition. Oxford University Press, 2012.

\section{Journal Article}

De Ly, Filip. "Non-Compete Clauses in International Contract-Les Clauses de Non-Concurrence Dans Les Contrats Internationaux." Int'l Bus. LJ (2006): 441. 
Easterbrook, Frank H. "Vertical arrangements and the rule of reason." Antitrust LJ 53 (1984): 135.

Fugate, Wilburg L. International Distribution Agreements. Antitrust Law Journal 43 (1974): 540-551

Iacobucci, Edward, and Ralph A. Winter. "European Law on Selective Distribution and Internet Sales: An Economic Perspective." ANTITRUST LJ 81 (2017): 47-64.

Incardona, Rossella. "Distribution Agreements under EC Competition Law." Available at SSRN 1185371 (2005).

Martin, Mervyn, Sole Distribution Agreements in the Context of the General Principles of Free Trade and Competition, pages 77-94, Syracuse Journal of International Law and Commerce 35, 2007.

Martin, Mervyn. "Sole distribution agreements in the context of the general principles of free trade and competition." Syracuse J. Int'l L. \& Com. 35 (2007): 77.

Petersmann, Ernst-Ulrich. "International competition rules for governments and for private business." Journal of World Trade 30, no. 3 (1996): 5-35.

Raad, Puya. "Effectiveness of EU Law and Policy on Vertical Restraints at Protecting Competition." Wroclaw Review of Law, Administration \& Economics 3, no. 1 (2013): 119-125. https://doi.org/10.2478/wrlae-20130047

\section{Thesis and Dissertation}

Chernobrovkin, Alexander. "International distribution and agency agreements in Russian law and practice in comparison to the European approach. Master Thesis of Advanced Studies in European Law, Ghent University Law School, 2011

Gajin, Dragan. Antitrust Aspects of Exclusive Distribution Agreements. CEU, Budapest College, 2011.

Macedo, Inês Silva. "Distribution agreements: ban on internet sales-towards a more economic based approach." PhD diss., 2015.

Hanni, Noona. Exclusive Transnational Distribution Agreements and NonCompete Clauses in Trade Between EU and US. Bachelors Thesis, University of Turku, Faculty of Law, 2019.

\section{Legal Instrument}

Treaty on the Functuoning of the European Union OJ C 326, 26.10.2012.

Comissions Regulation (EU) No 330/2010 of 20 April 2010 on the application of Article 101(3) of the Treaty on the Functioning of the European Union to categories of vertical agreements and concerted practices (Block Exemption regulation)

European Commissions Guidelines on Vertical Restraints (2010/C 130/01) (Vertical Guidelines) 
Sherman Antritrust Act of 1890

Clayton Antitrust Act of 1914

Green Paper on Vertical Restraints in EC Competition Policy 2010

Commissions notice on the definition of relevant market for the purposes of Community competition law (97/C 372 /03)

\section{Case Law}

C-56/65 - Société Technique Minière v Maschinenbau Ulm, Court of Appeal in Paris 1966

C-85/76 Hoffman-La Roche and Co v Commission 1979

Commissions decision 2003/675 Nintendo

Microsoft, 253 F.3d at 58 and Green Paper on Vertical Restraints in EC Competition Policy 1997

United States v. Imperial Chern. Indust., Ltd, 1952

United States v Bausch and Lomb Optical co, 321 U.S 707 (1944)

Cont'1 TV v GTE Sylvania Inc. 433 US 1977

Valley Liquors Inc, v Renfield Imps. Ltd., 678 F.2d 742, 745, 7th Cir. 1982

Tampa Elec. Co. v. Nashville Coal Co., 365 U.S. 320, 327-28 (1961)

Barr Labs., Inc. v. Abbott Labs., 978 F.2d 98, 111 (3d Cir. 1992)

Ingmar GB Ltd v Eaton Leonard Technologies Inc. Case C-381/98

Innovation Ventures LLC v. Liquid Manufacturing LLC, 315519 (Mich. Ct. App. 2014)

United States v Arnold Schwinn and Company 1967

Apani Southwest, Inc. v. Coca-Cola Enterprises, 300 F.3d 620, 625 (5th Cir. 2002)

Graphic Products Distributors, Inc. v. Itek Corp., 717 F.2d 1560, 1570 (11th Cir.1983)

Rothery Storage \& Van Co. v. Atlas Van Lines, Inc., 792 F.2d 210, 221 (D.C.Cir.1986)

Domed Stadium, 732 F.2d at 490.

\section{Website Content}

James C. Cooper, Luke M. Froeb, Daniel P. O'Brien, Michael G. Vita, A Comparative Study of United States and European Union Approaches to Vertical Policy. Accessed December 10, 2018.

www2.owen.vanderbilt.edu/lukefroeb/froeb.papers/vertical/2006.GMU.pdf

Mitnick, Joel, Katzmerzak, Karen, Huston, Peter K, Vertical Agreements United States. Sidley Austin LLP. Accessed December 10, 2018. www.gettingthedealthrough.com/area/41/jurisdiction/23/verticalagreements-2017-united-states / 
Harrison, Patrick J, Vertical Agreements. Law and Business research 2018. Accessed December 10, 2018. www.sidley.com/$\angle$ media/publications/va2018usa.pdf

Miller Canfield. Michigan Supreme Court Makes Commercial Non-Compete Agreements Easier to Enforce. Accessed December 10, 2018 www.millercanfield.com/newsletter-

478.html?click_source=sitepilot07!2718!c3VibWlzc2lvbnNAbGV4b2xvZ3ku $\underline{Y 29 t}$

Slaughter and May. the EU Competition Rules on Vertical Agreements. Accessed December 10 , 2018. https://www.slaughterandmay.com/media/64575/the-eu-competitionrules-on-vertical-agreements.pdf

Arnold, David, Seven Rules of International Distribution, Harvard Business Review November-December 2000 issue. Accessed December 17, 2018. www.hbr.org/2000/11/seven-rules-of-international-distribution

OECD. Glossary of Statistical Terms. Accessed December 17, 2018. www.stats.oecd.org/glossary/detail.asp?ID $=3153$

European Commission. Abuse of a Dominant Position. Accessed December 17, 2018. http://ec.europa.eu/competition/consumers/abuse_en.html

\section{Other Document}

Benguria, Felipe. Production and Distribution in International Trade: Evidence from Matched Exporter-Importer Data. Job Market Paper 2013. 